\title{
Meaning and Effects of the European Convention on Human Rights and of the Judgments of the European Court of Human Rights in Germany
}

\author{
Stefanie Schmahl* \\ Universität Würzburg \\ 2 Sanderring, Würzburg, 97070, Germany
}

Received 15.05.2017, received in revised form 09.06.2017, accepted 13.06.2017

\begin{abstract}
The European Convention on Human Rights, its protocols and the case-law of the European Court of Human Rights are shaping the German legal order to a considerable extent, although the Convention formally takes only the hierarchical rank of a simple federal statute. The reason for this triumphant success of the Convention guarantees in Germany is that the European Convention is much more than an ordinary international treaty: it limits the power of the State in the interests of individual freedom, equality and human dignity. It is true that the European Court of Human Rights has no competence to abolish national laws that are in conflict with the Convention. Nevertheless, the Strasbourg Court has a significant indirect influence on the national legal order and, in a way, performs constitutional functions in substance. The European Court of Human Rights is legitimized philosophically by the fact that the European Convention on Human Rights does not draw up its own sovereignty but is exclusively called upon to interfere with and to limit other sovereign powers, namely those of its High Contracting Parties.
\end{abstract}

Keywords: Hierarchical rank of the European Convention of Human Rights in Germany, Basic Law's commitment to international law, normative guiding function of the European Convention of Human Rights, precedence effect of the judgments of the European Court of Human Rights, obligation of termination and non-repetition of Convention infringements, Görgülü decision (Federal Constitutional Court), judgment on preventive detention (Federal Constitutional Court), Caroline decision (Federal Constitutional Court), Treaty Override decision (Federal Constitutional Court), constitutional functions of the European Court of Human Rights.

DOI: 10.17516/1997-1370-0089.

Research area: law.

\section{The Hierarchical Rank of the Convention}

Like all international treaties, the European Convention of Human Rights (ECHR) and its protocols, in so far as they came into force for the Federal Republic of Germany, have the status of an ordinary federal statute (see Article 59 (2) sentence 1 of the Basic Law) ${ }^{1}$. This formal allocation of international treaties to the same hierarchical rank as federal statutes leads, on

(c) Siberian Federal University. All rights reserved

* Corresponding author E-mail address: 1-europarecht@jura.uni-wuerzburg.de 
one hand, to the fact that international treaties enjoy pre-eminence to all statutes of the Länder (see Article 31 of the Basic Law) ${ }^{2}$. On the other hand, in the event of a conflict between a treaty provision and German federal statutes, German courts must observe and apply the guarantees of the international agreement within the limits of a methodically justifiable interpretation ${ }^{3}$. This method of interpretation is even applied to those federal statutes which are later adopted as an international human rights treaty. Particularly in order not to let the effects of the ECHR pro futuro be exhausted, the lex posterior principle is overcome; the human rights guarantee has to be applied as the more specific law ${ }^{4}$. In its recent decision of 2015 on the so-called "treaty override" in double tax treaties, the Federal Constitutional Court (FCC) expressly excludes human rights conventions on the possibility of overruling by means of subsequent domestic laws 5 .

\section{The Strasbourg Case-Law as an Important Interpretation Aid}

Moreover, according to the established case-law of the Federal Constitutional Court, the ECHR is, in spite of its formal hierarchical rank as a simple federal statute, to be consulted even in the interpretation of the fundamental rights enshrined in the Basic Law. As early as 1987, the FCC declared that the content and development of the Convention were to be taken into account when interpreting the Basic Law, whereby the jurisprudence of the European Court of Human Rights (ECtHR) serves as an important interpretation aid'. In its renowned "Görgülü" decision of 2004, the Federal Constitutional Court once again explicitly pointed out the particular importance of the decisions of the ECtHR, because they reflected the current state of development of the Convention and its protocols? This case-law on the constitutional significance of the Convention and the judgments taken by the Strasbourg Court has been reaffirmed by the FCC in the context of constitutional complaints against the German preventive detention provisions in 2011. The significance of the Convention and the case-law of the ECtHR for the German Constitution is the expression of the Basic Law's commitment to international law (Völkerrechtsfreundlichkeit), since the Basic Law encourages the exercise of the State sovereignty through the law of international agreements and therefore is, if possible, to be interpreted in such a way that no conflict arises with duties under public international law?.

\section{The Effects of the Strasbourg Case-Law in the German Legal Order}

The precedent effect of the Strasbourg judgments is thus firmly established in Germany. Its function to give normative guidance must be taken into account in all proceedings before national courts, even if the judgments of the ECtHR are not directed against the Federal Republic of Germany. This is because the Strasbourg Court's decisions in proceedings against other States parties give the States, that are not involved, an occasion to examine and, if necessary, to review their domestic legal systems and to orient themselves to the relevant caselaw of the $\mathrm{ECtHR}^{10}$. From the international law perspective, this obligation of orientation follows from Article 1 ECHR, according to which the High Contracting Parties shall secure to everyone within their jurisdiction the rights and freedoms set out in the Convention. At the domestic level, the Basic Law's principle of the commitment to international law argues for a human-rightscompliant interpretation of the German legal order $^{11}$.

If the Federal Republic of Germany itself is affected by a judgment of the Strasbourg Court as a party to the proceedings, there is even a direct binding effect and a substantive res judicata. It 
is true that the judgments of the ECtHR, which under Articles 44 and 46 ECHR become final and formally non-appealable, do not have any effect of abolition or annulment but can only declare the incompatibility of national judgments and statutes with the Convention ${ }^{12}$. Nevertheless, the States parties are obliged, in all cases where the Court finds a breach of the respondent State, to respect the final judgment of the ECtHR, and to put an end to, or, at least, not to repeat the declared violation of the Convention, to restore the state of affairs and to redress so far as possible the effects of the violation ${ }^{13}$. This obligation of termination and non-repetition of the infringement, which follows from Article 46 ECHR, applies to the State as a party to the proceedings, and therefore to all the legislative, executive and judiciary bodies acting on its behalf, as far as they are concerned by the case $^{14}$. At the domestic level, the binding effect shown here follows from the rule of law as laid down in Article 20 (3) of the Basic Law, since the respect for the statute and law also includes the guarantees of the ECHR and its protocols ${ }^{15}$.

The way in which the State affected by a judgment of the ECtHR eliminates the infringement of the Convention is, in principle, left to the decision of its bodies ${ }^{16}$. The selected means of eliminating the violation must, however, lead to a result which takes account of the requirements laid down by the Strasbourg Court in its judgment to remedy the infringement ${ }^{17}$. If the Court declares a national provision to be contrary to the Convention and if the breach cannot be remedied by mere interpretation of the provision in conformity with the ECHR when applied in practice, the national legislature must act. In this respect, the legislator has a margin of discretion how to alter the national provision $^{18}$, which, however, shrinks to zero when the national legal order reveals structural and systemic deficiencies identified by the so-called "pilot judgment procedure" by the ECtHR ${ }^{19}$. If an administrative act is contrary to the Convention and the violation is still ongoing, the national administrative authority shall cancel this act, subject to its margin of appreciation in each single case $^{20}$. Under the same conditions, administrative practice that is in violation of the Convention must be modified or amended, and courts may establish the duty to do this ${ }^{21}$. If, on the other hand, the ECtHR finds that a domestic judicial decision has infringed the Convention, the legal situation is more complicated. Because of the requirement of exhaustion of domestic remedies prior to the lodging of an individual complaint (see Article 35 (1) ECHR), the judgments of national courts reviewed by the ECtHR are, as a rule, final and non-appealable. The Strasbourg Court has no competence to exempt from the domestic principle of res judicata. In order to bring an end to the infringement of the Convention, it is therefore appropriate to open up the possibility of reopening judicial proceedings in national law ${ }^{22}$. Nowadays, in Germany several procedural statutes provide for retrial in cases where the ECtHR has declared a judgment of a German court to be contrary to the Convention ${ }^{23}$. If there is no possibility of retrial, the legal view of the ECtHR should at least be used in new proceedings in order not to repeat the violation.

Against this background, it is to be welcomed that the FCC, in its judgment on the preventive detention of 2011, has concluded that decisions of the ECtHR, which contain new aspects on the interpretation of the Basic Law, may be equivalent to a legally relevant change which might even lead to the final and non-appealable effect of the Federal Constitutional Court's decision being transcended ${ }^{24}$. It is true that the Federal Constitutional Court in the "Görgülü" ruling emphasized that the German courts were only obliged, under Article 46 ECHR, to take the guarantees of the Convention and the decisions of the ECtHR into consideration within the 
limits of a methodically justifiable interpretation of the domestic laws ${ }^{25}$. It is ultimately the task of the national courts to include a judgment of the ECtHR with regard to a partial system of the national legal order whose consequences are balanced and that is intended to achieve an equilibrium between differing fundamental rights $^{26}$. Nevertheless, the FCC, with its judgment on the preventive detention, shows that it is even prepared to revise its own case-law if the ECtHR finds that a violation has occurred ${ }^{27}$. The Court still opposes a "schematic parallelization" between the individual concepts provided for by the Convention guarantees on one hand, and by the fundamental rights enshrined in the Basic Law on the other, and it emphasizes the limits to interpretation that is open to international $\operatorname{law}^{28}$. At the same time, however, it points out that the Convention guarantees should be reconsidered through an "active reception process" in the context of the receiving constitutional system ${ }^{29}$. This way, German constitutional law is indeed substantially influenced by the views of the ECtHR, and it is brought into the most careful balance with the requirements of the Convention.

\section{The Impact of the Convention on the Jurisprudence of German Courts in Practice}

Not least because of this relatively open attitude towards the Strasbourg human rights system can we now observe considerable influences of the case-law of the ECtHR on the jurisprudence of German courts. Thus, the Federal Constitutional Court has already used Article 6 (2) ECHR as early as 1987 to establish the presumption of innocence not expressly provided for in the Basic $\mathrm{Law}^{30}$. In examining the proportionality of the deportation of a foreigner convicted in Germany, the FCC explained in a 2004 chamber decision in detail the legal views of the ECtHR with regard to Article $8 \mathrm{ECHR}^{31}$.
Even in its comparatively restrictive "Görgülü" decision, the Federal Constitutional Court confirms this convention-friendly line, although at the same time it emphasizes the limits to an interpretation that is open to international law ${ }^{32}$. More recently, the FCC increasingly takes the judgments of the ECtHR into account. A thorough examination of the Convention and the Strasbourg case-law can be found, for example, in the "Caroline II" decision of the Federal Constitutional Court of $2008^{33}$. In its famous "Lisbon" judgment of 2009, the FCC expressly refers to Article 3 of the First Additional Protocol to the Convention in order to outline the content of the principle of electoral equality according to the Basic Law ${ }^{34}$. In its judgment on the preventive detention issued in 2011, the Senate insists that the assessments of Article 7 (1) ECHR ${ }^{35}$ should give rise to a more precise definition of constitutional requirements for the design of a preventive deprivation of liberty independent of criminal liability which is qualitatively different from a punishment ${ }^{36}$. Freedom of religion and the principle of non-discrimination under Article 9 and Article 14 ECHR are also extensively discussed by the FCC in its latest decision of 2015 on the general headscarf ban for (female) teachers at public schools ${ }^{37}$. In its decision of July 2016, the FCC checks the medical compulsory treatment of persons placed under care not only on the basis of the fundamental rights of the Basic Law, but also on the basis of the ECHR guarantees and the standards set out in the UN Convention on the Rights of Persons with Disabilities ${ }^{38}$.

In the case-law of the federal supreme courts, the Convention guarantees are also being growingly taken into consideration in the interpretation and application of federal statutes. Particularly in the field of aliens law, the "normative guiding function" of the Convention is shown in various judgments of the Federal Administrative Court on deportation obstacles 
due to imminent death penalty or other impending violations of fundamental human rights ${ }^{39}$. In the case of German hunting law resolved in 2010, the Federal Administrative Court dealt with the caselaw of the ECtHR on compulsory membership in a French hunting association ${ }^{40}$. However, the Grand Chamber of the ECtHR still considered the German hunting law to be in violation of the Convention standards in $2012^{41}$, after which the German legislature amended the Federal Hunting Act in $2013^{42}$.

In the case-law of the Federal Court of Justice in criminal matters, the ECHR guarantees have for a long time characterized the interpretation and application of German criminal law provisions. This applies to the principle of acceleration in criminal matters ${ }^{43}$ as well as to the defendant's questioning rights against anonymous or absent witnesses $^{44}$, the imposition of the preventive detention $^{45}$ and the limits of the use of agents provocateurs $^{46}$. To a similar extent, the Federal Court of Justice in civil matters, for example, makes explicit reference to Article 5 (5) ECHR in order to justify claims for damages not only in the case of unlawful deprivation of liberty but also in the case of unlawful imprisonment conditions ${ }^{47}$. Since the "Caroline von Hannover" judgment of 2004, where the ECtHR gave prevalence to the privacy of prominent persons over the freedom of the press ${ }^{48}$, the Federal Court of Justice in civil matters has now adopted the graduated protection concept developed by the Strasbourg Court when interpreting and applying the German copyright statutes ${ }^{49}$.

Other federal supreme courts also deal extensively with the views given by the ECtHR. It is worth mentioning, for instance, the established case-law of the Federal Fiscal Court on the non-applicability of Article 6 (1) ECHR to tax procedures, which the ECtHR confirmed in $2002^{50}$. The Federal Social Court recognizes, in accordance with the case-law of the Strasbourg
Court, that public-law assets such as social security claims fall within the scope of Article 6 ECHR and Article 1 of the First Additional Protocol $^{51}$. The Federal Labour Court, under the general principle of equality of arms according to Article 6 (1) ECHR, has denied the right to be admitted to the testimony of a witness who had illegally listened to a telephone conversation ${ }^{52}$.

Finally, the constitutional courts of the Länder are also increasingly open towards the Convention guarantees and thereby emphasize the interpretation of these guarantees by the ECtHR in their judgments. For instance, the Constitutional Court of Brandenburg in 2011 stated that Article 26 of the Brandenburg Constitution, according to which marriage and family are to be protected and promoted by the community, must be interpreted in the light of Article 8 ECHR. Therefore, the concept of the family in the Brandenburg Constitution is not restricted to the so-called "core family", but also includes close relatives, such as grandparents and grandchildren ${ }^{53}$. In the meanwhile, the FCC has also turned to this line. After the family concept has been very narrow for decades in the jurisprudence of the Federal Constitutional Court $^{54}$, the First Senate in its decision of 2014 dissociates itself expressly from its former jurisprudence and makes clear that the protection of the family refers to a larger concept provided that there are intimate ties between the family members ${ }^{55}$.

\section{Concluding Assessment}

It is clear from all these decisions that the ECHR, its protocols and the case-law of the Strasbourg Court are now shaping the German legal order to a considerable extent, although the Convention formally occupies a simple federal statute place in the hierarchy. The reason for this triumphant success of the Convention guarantees in Germany is that the ECHR is much more than 
an ordinary international treaty: it limits the power of the State in the interests of individual freedom, equality and human dignity ${ }^{56}$. Above all, with regard to the Holocaust, the Convention has been created as an external control system in order to limit State powers in all areas where human rights protection is denied ${ }^{57}$.

It is true that the Strasbourg Court, as a judicial body of international law, has no competence to abolish national laws that are in conflict with the Convention. Its case-law is not intended to intervene directly in the domestic legal system ${ }^{58}$. However, the ECtHR can, in the individual or state complaint procedure, declare a domestic legal act to infringe human rights and, if necessary, can even demand compensation under Article $41 \mathrm{ECHR}^{59}$. Thus, the ECtHR has a significant indirect influence on the national legal order and, in a way, performs constitutional functions in substance. ${ }^{60}$ Unlike national constitutional courts, the Strasbourg Court is legitimized philosophically by the fact that the ECHR does not draw up its own sovereignty but is exclusively called upon to interfere with other sovereign powers, namely those of its High Contracting Parties ${ }^{61}$.
There may be plausible reasons why the task assigned to the ECtHR may not be accepted as a last guardian of minimum standards of human rights. The fact that the Federal Republic of Germany is one of the few Contracting Parties which provides for the possibility of a constitutional complaint and thus has extensive and effective domestic "self-cleaning mechanisms" is one of them. ${ }^{62}$ In addition, national courts operate regularly in a context which is determined not only by the applicable law, but also by the own legal tradition and culture. Therefore, the national judge often enjoys greater confidence in his own population ${ }^{63}$. On the other hand, the international judge is freer in his argument, precisely because there is no comparable cultural context on the international level. This is why the international judge can give meaningful impulses towards increasing freedom of the individual and why he also can liberate domestic courts' decisions from the suspicion of national-cultural bias $^{64}$. In these aspects, the overwhelming profit of the Convention and its judicial body, the ECtHR, for the domestic legal order cannot be underestimated.

$1 \quad$ See also FCC, order of 14 October 2004, 2 BvR 1481/04, para. 31. Görgülü, and FCC, judgment of 4 May 2011, 2 BvR 2365/09, para. 87. Sicherungsverwahrung, both with further references.

2 See FCC, order of 27 January 2015, 1 BvR 471/10, para. 149. Kopftuch II.

3 See FCC, order of 26 March 1987, 2 BvR 589/79, para. 39. Unschuldsvermutung. More recently see FCC, order of 14 October 2004, 2 BvR 1481/04, para. 32. Görgülü, and FCC, judgment of 4 May 2011, 2 BvR 2365/09, paras 86, 93 et seq. - Sicherungsverwahrung.

4 Clearly: FCC, order of 26 March 1987, 2 BvR 589/79, para. 39. Unschuldsvermutung. See also FCC, order of 14 October 2004, 2 BvR 1481/04, para. 32. Görgülü.

FCC, order of 15 December 2015, 2 BvL 1/12, para. 66. Treaty Override.

6 FCC, order of 26 March 1987, 2 BvR 589/79, para. 39. Unschuldsvermutung.

FCC, order of 14 October 2004, 2 BvR 1481/04, para. 38. Görgülü.

FCC, judgment of 4 May 2011, 2 BvR 2365/09, head note 2 a) and para. 88. Sicherungsverwahrung.

9 See FCC, judgment of 4 May 2011, 2 BvR 2365/09, para. 89. Sicherungsverwahrung. See also FCC, order of 14 October 2004, 2 BvR 1481/04, para. 33. Görgülü.

10 FCC, order of 14 October 2004, 2 BvR 1481/04, para. 39. Görgülü, with reference to Georg Ress. (1996). Wirkung und Beachtung der Urteile und Entscheidungen der Straßburger Konventionsorgane, Europäische Grundrechte-Zeitschrift, p. 350. See also FCC, judgment of 4 May 2011, 2 BvR 2365/09, para. 89. Sicherungsverwahrung.

11 Eckart Klein. (2010). Der Schutz der Grund- und Menschenrechte durch den Europäischen Gerichtshof für Menschenrechte, in Detlef Merten/Hans-Jürgen Papier (eds.), Handbuch der Grundrechte, vol. VI/1, § 150 para. 131.

12 See ECtHR, judgment of 13 June 1979, No. 6833/74, para. 58. Marckx. See also Jörg Polakiewicz, Die Verpflichtungen der Staaten aus den Urteilen des EGMR, 1993, pp. 217 et seq.

13 See ECtHR, judgment of 8 April 2004, No. 11057/02, para. 115. Haase; judgment of 30 June 2009, No. 32772/02, paras 61 et seq. Verein gegen Tierfabriken Schweiz No. 2. See also FCC, order of 14 October 2004, 2 BvR 1481/04, para. 41. Görgülü.

14 ECtHR, judgment of 8 April 2004, No. 11057/02, paras 115 et seq. Haase. 
15 FCC, order of 14 October 2004, 2 BvR 1481/04, para. 47. Görgülü.

16 See ECtHR, judgment of 13 June 1979, No. 6833/74, para. 58. Marckx; judgment of 8 April 2004, No. 11057/02, para. 115. Haase.

17 See ECtHR, judgment of 13 July 2000, Nos. 39221/98 et al., para. 249. Scozzari and Giunta.

18 FCC, order of 14 October 2004, 2 BvR 1481/04, para. 51. Görgülü.

19 As to the basic concept of the "pilot-judgment procedure" see ECtHR, judgment of 22 June 2004, No. 31443/96, para. 193. Broniowski. Further see, e.g., Stefanie Schmahl. (2008). Piloturteile als Mittel der Verfahrensbeschleunigung beim EGMR, in Europäische Grundrechte-Zeitschrift, pp. 369 et seq.; Marten Breuer. (2012). Zur Fortentwicklung der Piloturteilstechnik durch den EGMR, in Europäische Grundrechte-Zeitschrift, pp 1 et seq., both with further references. See, e.g., ECtHR, judgment of 8 April 2004, No. 71503/01, paras 202-203. Assanidze.

21 See FCC, order of 14 October 2004, 2 BvR 1481/04, para. 51. Görgülü.

22 See ECtHR, judgment of 1 March 2006, No. 56581/00, paras 120-124. Sejdovic; judgment of 17 September 2009, No. 10249/03, paras 150 et seq. Scoppola.

23 See, e.g., § 359 No. 6 Strafprozessordnung, § 580 No. 8 Zivilprozessordnung, § 79 Arbeitsgerichtsgesetz, § 199 Sozialgerichtsgesetz, and $\S 153$ Verwaltungsgerichtsordnung.

24 FCC, judgment of 4 May 2011, 2 BvR 2365/09, head note 1 and para. 82. Sicherungsverwahrung, with reference to ECtHR, judgment of 17 December 2009, No. 19359/04, paras 122 et seq. $M$.

25 FCC, order of 14 October 2004, 2 BvR 1481/04, paras 47, 62. Görgülü.

26 FCC, order of 14 October 2004, 2 BvR 1481/04, para. 57. Görgülü.

27 FCC, judgment of 4 May 2011, 2 BvR 2365/09, head note 1. Sicherungsverwahrung.

28 FCC, judgment of 4 May 2011, 2 BvR 2365/09, paras 91, 93. Sicherungsverwahrung. See also FCC, order of 14 October 2004, 2 BvR 1481/04, paras 47, 62. Görgülü.

29 FCC, judgment of 4 May 2011, 2 BvR 2365/09, para. 92. Sicherungsverwahrung, with reference to Peter Häberle, Europäische Verfassungslehre, 7 th edn. 2011, pp. 255-256.

30 FCC, order of 26 March 1987, 2 BvR 589/79, paras 39 et seq. Unschuldsvermutung.

31 FCC, order of 1 March 2004, Europäische Grundrechte-Zeitschrift 2004, p. 317, at 319.

FCC, order of 14 October 2004, 2 BvR 1481/04, paras 47 et seq. Görgülü.

See FCC, order of 26 February 2008, 1 BvR 1602/07, paras 52 et seq. Caroline II.

FCC, judgment of 30 June 2009, 2 BvE 2/08, para. 283. Lissabon.

35 See ECtHR, judgment of 17 December 2009, No 19359/04, paras 120-133. M., confirmed by ECtHR, judgment of 21 October 2010, No. 24478/02, paras 47, 51. Grosskopf.

36 FCC, judgment of 4 May 2011, 2 BvR 2365/09, paras 100 et seq. Sicherungsverwahrung.

37 FCC, order of 27 January 2015, 1 BvR 471/10, paras 148 et seq. Kopftuch II.

38 See FCC, order of 26 July 2016, 1 BvL 8/15, paras 87 et seq. Zwangsbehandlung.

39 See, e.g., Federal Administrative Court, judgment of 27 April 2010, 10 C 5.09, para. 17; judgment of 31 March 2013, 10 C 15.12, paras 22 et seq.; judgment of 15 April 2014, 10 B 16.14, para. 3.

40 See Federal Administrative Court, order of 23 June 2010, 3 B 89.09, paras 13 et seq., with regard to ECtHR, judgment of 29 April 1999, Nos. 25088/94 et al. Chassagnou; and also with regard to ECtHR, judgment of 10 July 2007, No. $2113 / 04$ Schneider.

41 See ECtHR, judgment of 26 June 2012, No. 9300/07, paras 72 et seq. Herrmann.

42 Federal Law Gazette 2013 I p. 1386; see also FCC, order of 23 November 2015, 1 BvR 1795/08.

43 Federal Court of Justice in criminal matters, BGHSt vol. 24, p. 239, at 240 et seq.

44 Federal Court of Justice in criminal matters, BGHSt vol. 46, p. 93, at 94 et seq. By contrast, see also ECtHR, judgment of 19 July 2012, No. 26171/07, para. 53. Hümmer, where the Court found a violation of Article 6 ECHR because the decisive nature of the witnesses' statements as introduced by the investigating judges' testimony in the absence of any strong corroborative evidence meant that the trial court was unable to conduct a fair and proper assessment of the reliability of such evidence.

45 Federal Court of Justice in criminal matters, BGHSt vol. 56, p. 248, at 251, with regard to FCC, judgment of 4 May 2011, 2 BvR 2365/09. Sicherungsverwahrung.

46 See, most recently, Federal Court of Justice in criminal matters, order of 19 May 2015, 1 StR 128/25, paras 7 et seq., and judgment of 10 June 2015, 2 StR 97/14, paras 19 et seq., both with references to ECtHR, judgment of 23 October 2014, No. 54648/09. Furcht.

47 Federal Court of Justice in civil matters, $B G H Z$ vol. 45, p. 58, at 65 et seq.; and vol. 122, p. 268, at 278 et seq.

48 See ECtHR, judgment of 24 June 2004, No. 59320/00. von Hannover; and, more recently, ECtHR, judgment of 7 February 2012, Nos. 40660/08 et al. von Hannover No. 2.

49 See, e.g., Federal Court of Justice in civil matters, Neue Juristische Wochenschrift. (2005). p. 56, at 58; and Neue Juristische Wochenschrift. (2011). p. 744, at 746.

50 See Federal Fiscal Court, BFHE vol. 141, p. 106, at 108; vol. 180, p. 316, at 324 et seq., and ECtHR, judgment of 12 July 2001, No. 44759/98, paras 20 et seq. Ferrazzini, as well as ECtHR, decision of 9 June 2005, No. 62512/00. H.M.

51 Federal Social Court, $B S G E$ vol. 81, p. 1, at 15; see also Federal Social Court, judgment of 5 February 2008, B 2 U 10/07 R, para. 37.

52 Federal Labor Court, $B A G E$ vol. 87, p. 31, at 40 et seq.

53 Constitutional Court of Brandenburg, judgment of 15 July 2011, 22/11, 1/11 eA, paras 19 et seq.

54 See, e.g., FCC, order of 31 May 1978, 1 BvR 683/77, para. 43. Familiennamen.

55 See FCC, order of 24 June 2014, 1 BvR 2926/13, paras 23 et seq. Großeltern-Vormundschaft. 
56 Stefanie Schmahl. (2008). Grundrechtsschutz im Dreieck von EU, EMRK und nationalem Verfassungsrecht, in Europarecht, Beiheft 1, p. 7, at 37 .

57 See Jörg Paul Müller (2000), in Mélanges à la mémoire de Rolv Ryssdal. p. 957, at 959 et seq.

58 See FCC, order of 14 October 2004, 2 BvR 1481/04, para. 45. Görgülü.

59 ECtHR, judgment of 13 June 1979, No. 6833/74, para. 58. Marckx.

60 See Christian Walter. (1999). Die Europäische Menschenrechtskonvention als Konstitutionalisierungsprozeß, in Zeitschrift für ausländisches und öffentliches Recht 59. p. 961, at 965.

${ }_{61} \quad$ See Schmahl (fn. 56), at pp. 37-38.

62 See, e.g., Renate Jaeger (2005). Menschenrechtsschutz im Herzen Europas, in Europäische Grundrechte-Zeitschrift, p. 193, at 199 et seq.

63 Wolfgang Hoffmann-Riem. (2002). Kohärenz der Anwendung europäischer und nationaler Grundrechte, in Europäische Grundrechte-Zeitschrift. p. 473, at 479.

64 See Stefanie Schmahl. (2012). Grundrechtsschutz im föderalen Europa, in Ines Härtel (ed.), Handbuch Föderalismus, Vol. IV, p. 411, at 442 .

\section{Значение и влияние}

\section{Европейской конвенции по правам человека \\ на решения Европейского суда \\ по правам человека в Германии}

\section{С. Шмаль}

Вюрибургский университет

Германия, 97070, Вюрибург, Sanderring, 2

Европейская конвенция о защите прав человека и основных свобод, ее протоколы, а также правоприменительная практика Европейского суда по правам человека в значительной мере формируют правовой порядок Германии, хотя формально в иерархии правовой системы Конвенция является не более чем федеральным законом. Причина триумфального успеха Конвениии в Германии заключается в том, что она имеет больиий вес, чем заурядный международный договор: она ограничивает власть государства для защиты личной свободы граждан, их человеческого достоинства и поддержки их равенства. Европейский суд по правам человека действительно не имеет права отменять начиональные законы, противоречащие положениям Конвенции; но тем не менее Страсбургский суд способен оказывать значительное косвенное влияние на национальный правовой порядок и даже в определенной степени выполнять конституиионные функиии. Философское значение Европейского суда по правам человека гарантируется тем фактом, что Европейская конвенция о защите прав человека и основных свобод не утверждает его суверенность, но при этом дает ему исключительное право вмешиваться в деятельность ее участников на высочайшем уровне и ограничивать ее.

Ключевые слова: иерархическое положение Европейской конвенции о защите прав человека и основных свобод в Германии, зависимость основного права от международных законов, нормативная руководящая функиия Европейской конвенции о защите прав человека и основных свобод, прецедентный характер решений Европейского суда по правам человека, обязательство о прекращении и недопущении повторных нарущений Конвенщии, решение по делу Гёргюлю (Федеральный конституциионый суд), решение о содержании под стражей до суда (Федеральный конституционный суд), решение по делу Каролины (Федеральный конституционный суд), решение о превосходстве внутренних законов (Федеральный конституционный суд), конституиионные функиии Европейского суда по правам человека.

Научная специальность: 12.00.00 - юридические науки. 